\title{
Land Use Land Cover Dynamics on Sediment Yield Modeling of Angar Sub-Basin, Blue Nile Basin, Ethiopia
}

\author{
Miressa Bayisa, Dereje Adeba \\ Department of Hydraulic and Water Resources Engineering, Wollega University, Nekemte, Ethiopia
}

Email address:

miressabaye4@gmail.com (M. Bayisa)

\section{To cite this article:}

Miressa Bayisa, Dereje Adeba. Land Use Land Cover Dynamics on Sediment Yield Modeling of Angar Sub-Basin, Blue Nile Basin, Ethiopia. International Journal of Energy and Power Engineering. Vol. 10, No. 4, 2021, pp. 62-74. doi: 10.11648/j.ijepe.20211004.11

Received: July 19, 2021; Accepted: August 3, 2021; Published: August 26, 2021

\begin{abstract}
The high land of Ethiopia is characterized as a region of high rates of land degradation and soil erosion, especially the Blue Nile Basin, where the eroded area is due to a significant change of land use/cover. This study aimed to estimate the sediment yield of Angar sub-basin using the Soil and Water Assessment Tool (SWAT) model interface of GIS at the outlet. The land use map of 1990, 2005, and 2018 was identified from TM, ETM+, and OLI TIRS satellite images, and the accuracy was checked using the error matrix and Kappa statistic. The streamflow and sediment were calibrated and validated to check the model performance. The model performance has been evaluated using statistical parameters of coefficient of determination $\left(\mathrm{R}^{2}\right) 0.75$ to 0.94 for calibration \& 0.77 to 0.95 for validation and Nash-Sutcliffe efficiency (NSE) 0.60 to 0.93 for calibration \& 0.64 to 0.92 for validation. The annual average suspended sediment was $17.64 \mathrm{t} / \mathrm{ha} / \mathrm{yr}$. and the simulated annual average sediment yield was $18 \mathrm{t} / \mathrm{ha} / \mathrm{yr}, 19 \mathrm{t} / \mathrm{ha} / \mathrm{yr}$. \& $22 \mathrm{t} / \mathrm{ha} / \mathrm{yr}$. for land use of 1990, 2005, and 2018 respectively. The sediment severity percentage increased from land-use of 1990 to 2018 by $24.32 \%$. due to the expansion of agricultural activities and settlement areas.
\end{abstract}

Keywords: Angar Sub-basin, Arc SWAT, Land Use/Cover, Sediment Yield

\section{Introduction}

\subsection{General Background}

Expanding human requirements and economic activities are placing ever-increasing pressures on land resources, creating conflicts and resulting in sub-optimal use of both land and land resources. The land is a finite resource, while the natural resources it supports can vary over time and according to the management conditions and uses. The importance of land degradation among global issues is enhanced because of its impact on world food security and the quality of the environment [5].

The dynamic nature of land use arising from an increasing population, expansion of the agricultural land, and climatic change. In Ethiopia, the fast-growing rate of population and the density of livestock resulted in forest clearing and overgrazing. On the other side, Agricultural production in the highlands is dominated by cereal crops, which necessitates frequent soil mixing and provides very little ground cover at the start of the crop season, thus rendering it more susceptible to erosion and land degradation [15]. Expansion of agriculture, urbanization, deforestation, and the day-to-day activities of people settled in the Angar sub-basin resulted in a temporal and spatial change in land use land cover affected stream flow pathways and water balance [11]. Land-use change is a very important issue considering global dynamics and their response to hydrologic characteristics of soil and water management in a catchment. Catchments are sensitive to land use induced by human activities [4] and land cover changes are predicted to have an important effect on river flows and sediment yields.

Experimental data tend to indicate that changes in land use have a greater effect on sediment yield than on either total runoff or runoff intensity [9]. The removal of the vegetal cover from a land surface results in the initial increase in the resultant rate of removal of topsoil. Sediment is a serious ecological issue observed in Ethiopia, degrading the precious soil resources which are the basis of agricultural production and food for the country's population. Sediment yield reflects the influences of climate (precipitation), catchment properties (soil type, topography), and land use land cover and drainage 
properties (stream network form and density) [14]. Sedimentation in catchment outlets such as reservoirs, lakes, ponds, and dams is perhaps the most problematic outcome of soil erosion [13].

\subsection{Statement of the Problem}

Land use/cover dynamics directly influencing the natural hydrological systems that might play a crucial role in the economic development that needs management and conservation while using it to achieve its sustainable utilization.

Soil erosion and land degradation is a major problem in the Ethiopian highlands and loses about 1.3 billion metric tons of fertile soil every year and the degradation of land through soil erosion is increasing at a high rate [8], this is due to poor land use management and the lack of appropriate soil conservation measures in the country. Angar sub-basin is located in the Blue Nile basin, the part of highlands of Ethiopia, where the steep and long slope topography is severe soil erosion and land degradation. The increasing population and agricultural activities caused deforestation. This accelerates the removal of fertile productive soil by runoff and sediment yield due to land use/cover dynamics problems within the study area. Therefore, this study might be used for water resources management, land use planning, and environmental protections within the Angar sub-basin.

\subsection{Objectives of the Study}

a) To analyze and produce the land use land cover changes of Angar Sub-basin.

b) To estimate and compare the sediment yield of the subbasin under the land use/cover changes.

c) Characterizes the spatial variability of sediment yield mapping and identify hotspot area.

\section{Materials and Methods}

\subsection{Description of the Study Area}

Angar sub-basin is located in Ethiopia; in the southeastern part of the Blue Nile basin which has a drainage area of $7,980 \mathrm{~km}^{2}$. It is found in the East Wollega Zone of Oromia National Regional State between $10^{\circ} 95^{\prime}$ and $11^{\circ} 80^{\prime} \mathrm{N}$ latitudes and $36^{\circ} 70^{\prime}$ and $37^{\circ} 40^{\prime} \mathrm{E}$ longitudes. The western part is lowlands and the altitude of the sub-basin ranges between 868 to 3144 m.a.s.l. The geology formation was Adigrat Sandstone, Wollega Basalt, Granite, and Clastics deposits [3]. The soils type were; Eutric Cambisols, Camblic Arenosols, Haplic Alisols, and Eutric Nitosols. The watershed is characterized by tepid to cool and sub-humid mid highlands and hot to warm sub-humid lowlands and gained the annual rainfall ranging between $1352 \mathrm{~mm}$ and $1874 \mathrm{~mm}$.

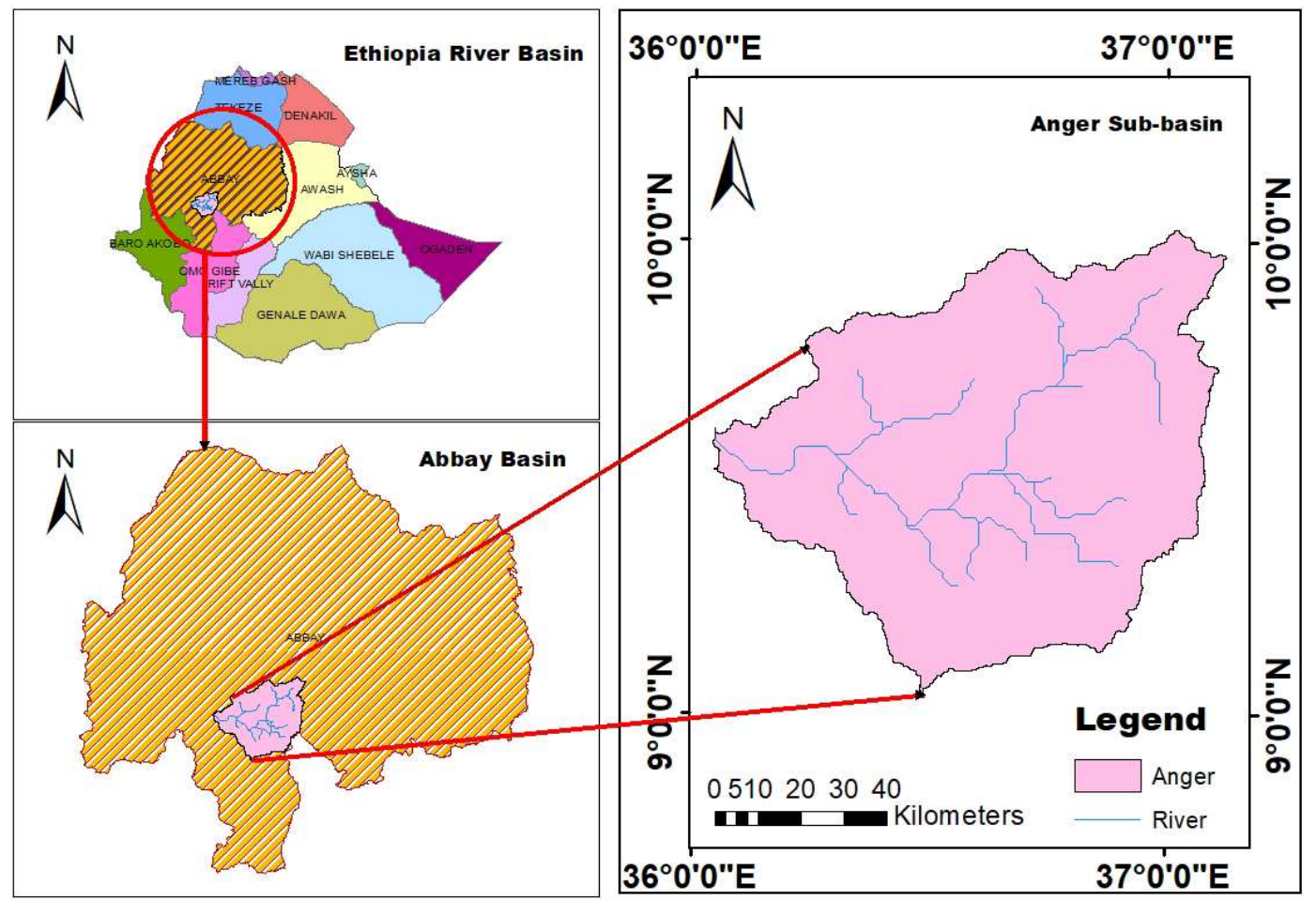

Figure 1. Location of the study area.

\subsection{Tools and Methods}

The main tools and data used for input data preparation and analysis were: Arc SWAT, SWAT-CUP, PCPSTAT, Dew02.exe, DEM, Meteorological data, Hydrological data, land use land cover map, and soil map.

\subsection{Description of SWAT Model}

The interface of the SWAT model is compatible with 
ArcGIS that can integrate numerous available geospatial data to accurately represent the characteristics of the watershed. SWAT is a public domain software-enabled model actively supported by the USDA Agricultural Research Service [1] at the Backland Research \& Extension Center in Temple, Texas, USA. It is a semi-distributed physically-based simulation model and can predict the impacts of land-use change and management practices on hydrological regimes in watersheds with varying soils, land use, and management conditions over long periods and primarily as a strategic planning tool [10].

The major hydrologic processes that can be simulated by this model include evapotranspiration, surface runoff, infiltration, percolation, shallow aquifer, and deep aquifer flow, and channel routing [1]. The large-scale spatial heterogeneity of the study area is represented by dividing the watershed into sub-basins. Each sub-basin is further discretized into a series of hydrologic response units (HRUs), which are unique soil-land use combinations. Soil water content, surface runoff, nutrient cycles, sediment yield, crop growth, and management practices are simulated for each HRU and then aggregated for the sub-basin by a weighted average.

\subsection{Hydrological Components of SWAT}

The Simulation of the hydrology of a watershed is done in two separate divisions. One is the land phase of the hydrological cycle that controls the amount of water, sediment, nutrient, and pesticide loadings to the main channel in each sub-basin. The second division is the routing phase of the hydrologic cycle that can be defined as the movement of water, sediments, nutrients, and organic chemicals through the channel network of the watershed to the outlet. In the land phase of the hydrological cycle, SWAT simulates the hydrological cycle based on the water balance equation [10].

$$
\text { SWt }=S W o+\sum_{i=1}^{t}(\text { Rday }- \text { Qsurf }- \text { Ea }- \text { Wseep }- \text { Qgw })(1)
$$

In which, SWt is the final soil water content on a day ( $\mathrm{mm}$ $\mathrm{H}_{2} \mathrm{O}$ ), $\mathrm{t}$ is the time (days), SWO is initial soil water content on a day $\mathrm{i}\left(\mathrm{mm} \mathrm{H}_{2} \mathrm{O}\right), \mathrm{R}_{\text {day }}$ is the amount of precipitation on a day $\mathrm{i}\left(\mathrm{mm} \mathrm{H}_{2} \mathrm{O}\right), \mathrm{Q}_{\text {surf }}$ is of the surface runoff on a day $\mathrm{i}(\mathrm{mm}$ $\left.\mathrm{H}_{2} \mathrm{O}\right), \mathrm{E}_{\mathrm{a}}$ is the evapotranspiration on a day $\mathrm{i}\left(\mathrm{mm} \mathrm{H}_{2} \mathrm{O}\right)$, $\mathrm{W}_{\text {seep }}$ is the amount of water entering the vadose zone from the soil profile on a day $\mathrm{i}\left(\mathrm{mm} \mathrm{H}_{2} \mathrm{O}\right), \mathrm{Q}_{\mathrm{gw}}$ is the amount of return flow on a day $\mathrm{i}\left(\mathrm{mm} \mathrm{H}_{2} \mathrm{O}\right)$.

Surface runoff occurs whenever the rate of precipitation exceeds the rate of infiltration. SWAT offers two methods for estimating surface runoff. Using daily or sub-daily rainfall, SWAT simulates surface runoff volumes and peak runoff rates for each HRU. The surface runoff in the catchment is estimated by the model using the SCS curve

$$
\mathrm{Sed}=11.8 *\left(\mathrm{Q}_{\text {surf }} * \mathrm{q}_{\text {peak }} * \mathrm{~A}_{\mathrm{hru}}\right){ }^{0.56} * \mathrm{~K}_{\text {usle }} * \mathrm{C}_{\text {usle }} * \mathrm{P}_{\text {usle }} * \mathrm{LS}_{\mathrm{usle}} * \mathrm{CFRG}
$$

Where: Sed is the sediment yield on a given day (tons), $\mathrm{Q}_{\text {surf }}$ is surface runoff from a watershed in ( $\mathrm{mm}$ water $\left./ \mathrm{ha}\right)$, $\mathrm{q}_{\text {peak }}$ is peak runoff rate $\left(\mathrm{m}^{3} / \mathrm{s}\right), \mathrm{A}_{\text {hru }}$ is area of hydrologic response unit (ha), $K_{\text {usle }}$ is the USLE soil erodibility factor, number method [12].

$$
\mathrm{Q} \operatorname{surf}=\frac{(\mathrm{Rday}-\mathrm{Ia})^{2}}{(\mathrm{R}-\mathrm{Ia}+\mathrm{S})}
$$

In which, $\mathrm{Q}_{\text {surf }}$ is the accumulated runoff or rainfall excess $(\mathrm{mm}), \mathrm{R}_{\text {day }}$ is rainfall depth for the day $(\mathrm{mm}), \mathrm{I}_{\mathrm{a}}$ is the initial abstraction which includes surface storage, interception, and infiltration before runoff $(\mathrm{mm})$ and $\mathrm{S}$ is the retention parameter.

The retention parameter varies spatially due to changes in soils, land use, management, and slope and temporally due to changes in soil water content. The retention parameter is defined by

$$
\mathrm{S}=25.4 *\left(\frac{1000}{C N}-10\right)
$$

Where: $\mathrm{CN}$ is the curve number for the day (its value is the function of land use soil permeability and soil hydrologic group). The initial abstraction, Ia, is commonly approximated as $0.2 \mathrm{~S}$.

Then the above equation becomes:

$$
\mathrm{Q} \operatorname{surf}=\frac{(\text { Rday }-0.2 \mathrm{~S})^{2}}{(\text { Rday }+0.8 \mathrm{~S})}
$$

Therefore, the runoff will occur when $R_{\text {day }}>I_{a}$.

The peak runoff rate is the maximum runoff flow rate that occurs in a given rainfall event. The peak runoff rate is an indicator of the erosive power of a storm and is used to predict sediment loss. SWAT calculates the peak runoff rate with a modified rational method:

$$
\text { Qpeak }=\frac{\mathrm{C} * \mathrm{I} * \mathrm{~A}}{3.6}
$$

Where: $Q_{\text {peak }}$ is peak runoff rate $\left(\mathrm{m}^{3} / \mathrm{s}\right), C$ is a runoff coefficient, A is a sub-basin area $\left(\mathrm{km}^{2}\right)$, I is rainfall intensity $(\mathrm{mm} / \mathrm{hr})$ and 3.6 is a unit conversion factor.

\section{SWAT Sediment Model}

The SWAT model can be used for sediment yield predictions for planning and management of water resources and reservoir sediment controls at the catchment scale. The modeling method applies to temporal and spatial analysis of sediment yields of which the results are essential for watershed management strategies. The model can also provide a better understanding of sediment transport and deposition processes by overland flow and allow reasonable prediction and forecasting.

The current version of the model routes the maximum amount of sediment in a reach as a function of the peak channel velocity and estimates sediment yield for each HRU using Modified Universal Soil Loss Equation (MUSLE) [16].

$\mathrm{C}_{\text {usle }}$ is the USLE land cover and management factor, $\mathrm{P}_{\text {usle }}$ is USLE support practical factor, LS $_{\text {usle }}$ is the USLE topographic factor, and CFRG is the coarse fragment factor. 


\subsection{SWAT Model Input}

\subsubsection{Digital Elevation Model (DEM)}

DEM is the first input of the SWAT model for delineating the watershed. It describes the elevation of any point in a given area at a specific spatial resolution. It is the basic input of the ArcGIS integrated SWAT hydrologic model to delineate the watershed, extract information about the topography/elevation of the watershed, and analyze the drainage patterns of the land surface terrain. Sub-basin parameters such as slope gradient, slope length of the terrain, and the stream network characteristics were also derived from the DEM. For this study, $30 \mathrm{~m}$ by $30 \mathrm{~m}$ DEM of the Blue Nile basin of Ethiopia was collected from the Ministry of Water, Irrigation, and Energy of Ethiopia. The DEM was extracted and projected to UTM 37 North and D_WGS_1984 datum using ArcGIS 10.3.

\subsubsection{Land Use Land Cover Data}

Land use main input data of the SWAT model to describe the Hydrological Response Units (HRUs) of the watersheds. The land use of the Angar sub-basin over 29 years period from 1990 to 2018 was prepared from Landsat images (Landsat-5 TM, Landsat-7 ETM+, and Landsat-8 OLI_TIRS), downloaded from U.S Geological Survey (USGS) Center for Earth Resources Observation and Science (EROS). The images used were Orthorectified to a Universal Transverse Mercator Projection using Datum WGS (World Geodetic System) 84 Zone 37 and the land use types were made compatible with the input needs of the model.

\subsubsection{River Discharge and Sediment Data}

The stream flow and sediment data were used for calibration and validation of the model. The daily observed streamflow data for the 1990 -2005 years, at the Great Angar gauging station was obtained from the Ministry of Water, Irrigation, and Electricity (MoWIE), hydrology department. The streamflow homogeneity tested by RAINBOW, that offers a test of homogeneity and independent data, which is based on the cumulative deviations from the mean data. Measuring the average suspended-sediment concentration in stream-flow is a time-consuming and expensive operation and for these reasons, I make considerable use of suspended sediment rating curves. Sediment rating curves are widely used to estimate the sediment load being transported by a river that expresses the average relation between river discharge and suspended sediment concentration for certain existing data. Such a relationship is usually established by regression analysis, and the curves are generally expressed in the form of a power-law type equation [2].

$$
\mathrm{Qs}=\mathrm{aQ}{ }^{\mathrm{b}}
$$

Where: Qs is suspended sediment (ton/day), $a$ and $b$ are regression coefficient and exponent and $\mathrm{Q}$ is river discharge. The sample of suspended sediment was measured by $(\mathrm{mg} / \mathrm{l})$ to convert sediment load (ton/day) by using the following formula:

$$
\mathrm{Qs}=0.0864 * \mathrm{Cs} * \mathrm{Q}
$$

Where: Qs is sediment load (ton/day), Cs is sediment concentration $(\mathrm{mg} / \mathrm{l})$, Q river flow $\left(\mathrm{m}^{3} / \mathrm{s}\right)$ and 0.0864 conversion factor.

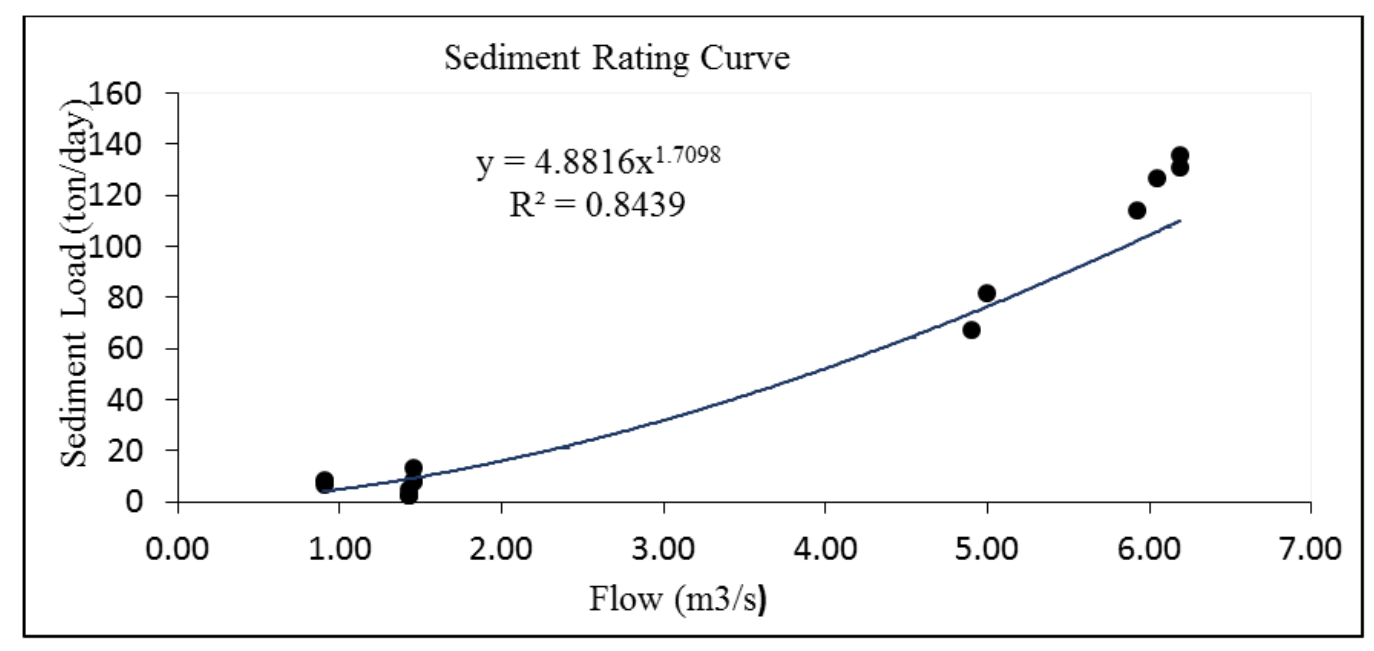

Figure 2. Sediment rating curve of Angar sub-basin at Great Angar gauging station.

\subsubsection{Weather Data}

The daily hydro-meteorological data collected from the meteorological stations have a missing value. Therefore, using a weather generator solves such types of the problem by generating data from the observed one. The weather generator parameters were developed by using excel (pivot table), dew point temperature calculator software, DEW02 and PCPstat to calculate average monthly and average daily precipitation, standard deviation, skew coefficient, probability of a wet day following a dry day and average number of days of precipitation in a month. After HRU analysis, the weather data (rainfall, temperature, solar radiation, wind speed and relative humidity data) were loaded from weather station locations into the current project and assign weather data to the sub-watersheds. 


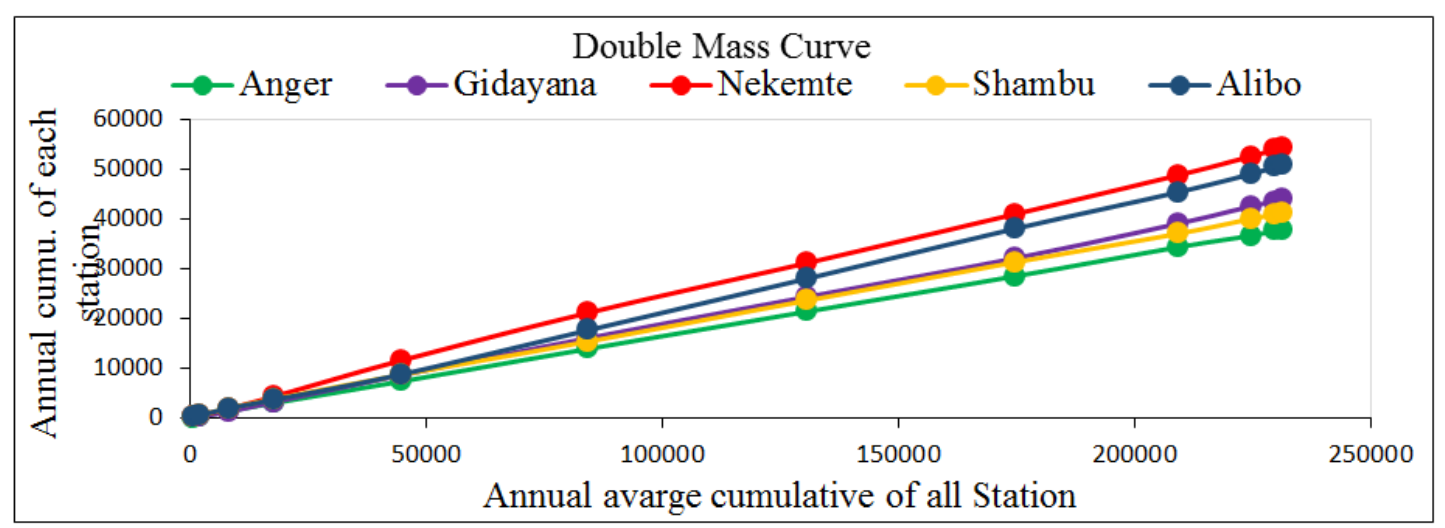

Figure 3. The double mass curve for selected stations.

\subsection{Model Setup}

After SWAT input data were prepared, the SWAT project setup was created for watershed delineation. The DEM was extracted and projected to UTM 37 North and D_WGS 1984 datum for stream definition, outlet and inlet definition, watershed outlets selection and definition, and calculation of sub-basin parameters. After watershed delineation, HRU definition with multiple options that accounts for $10 \%$ land use, $20 \%$ soil, and $10 \%$ slope threshold combination was used. After sub-basin discretization, the writing up of the prepared weather data to the model was done.

SWAT simulation was also done using the HRUs and weather data inputs. Sensitivity analysis of SWAT simulation using 26 years of recorded river flow and sediment was also done for identifying the most sensitive parameters.

The calibration of flow and sediment simulations was performed using the identified sensitive parameters for the periods 1992 - 1999 and also validation was done for the periods $2000-2005$. The model performance was evaluated using a coefficient of determination $\left(\mathrm{R}^{2}\right)$ and Nash-Sutcliffe Efficiency (NSE).

$$
R^{2}=\frac{\sum_{i=1}^{n}\{[Q i-Q m][S i-S m]\}}{\sqrt{\sum_{i=1}^{n}[Q i-Q m]^{\wedge} 2} \sqrt{\sum_{i=1}^{n}[S i-S m]^{\wedge} 2}}
$$

Where: $\mathrm{R}^{2}$ is coefficient of determination, Qi is observed hydrologic variable, $\mathrm{Qm}$ is mean observed hydrologic variable, $\mathrm{Si}$ is model simulated output, $\mathrm{Sm}$ is mean of the model simulations and $\mathrm{n}$ is the total number of observations.

Nash-Sutcliffe Efficiency (NSE):
Determines the relative magnitude of the residual variance compared to the measured data variance is calculated as follows.

$$
\mathrm{ENS}=1-\frac{\sum_{1}^{\mathrm{n}}(\mathrm{Qi}-\mathrm{Si})^{2}}{\sum_{1}^{\mathrm{n}}(\mathrm{Qi}-\mathrm{Qm})^{2}}
$$

Where: $\mathrm{Si}$ is model simulated output, Qi is observed hydrologic variable, Qm is mean of the observations that NSE uses as a benchmark against which performance of the hydrologic model is compared and $\mathrm{n}$ is the total number of observations.

\section{Results and Descriptions}

\subsection{Land Use Land Cover Change Analysis}

The accuracy assessment of images was carried out and the land use/cover map showing five classes (agriculture land, forest, shrubs land, grass, water body, and built-up) of land use/cover were created using these classes for 1990, 2005, and 2018. The spatial analysis of land cover has been performed to describe the overall land use/cover patterns throughout the watershed. The accuracy assessment was performed by using land-use maps, ground truth points, and Google Earth. The 2005 land use classification has shown, user's accuracy and producer's accuracy are greater than $85 \%$, as well the overall accuracy of $89 \%$ (Table 1 ).

These values indicate the land sat and the methodologies used were so accurate. The Kappa coefficient was also calculated, with a value of $\mathrm{K}=82 \%$, which indicated the classification is almost perfect since it is greater than $80 \%$.

Table 1. Confusion Matrix of LULC During 2005.

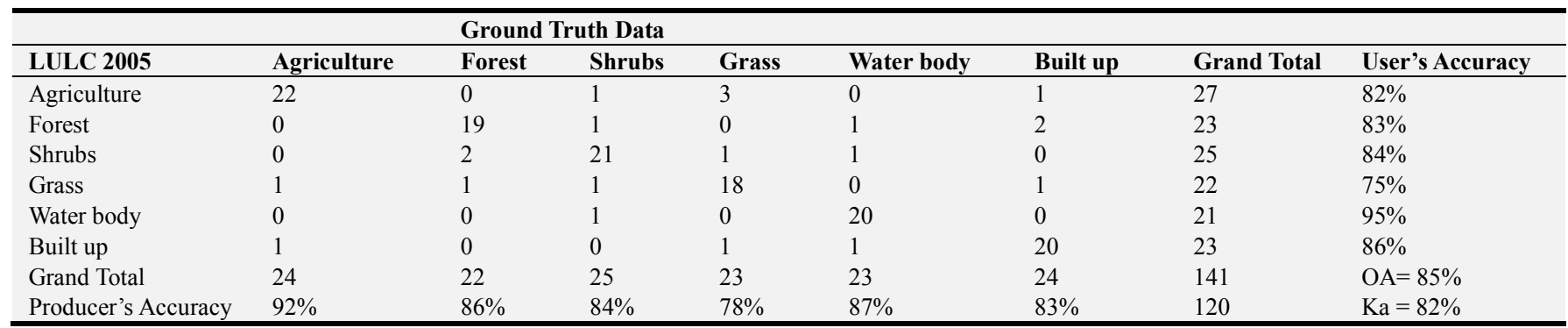




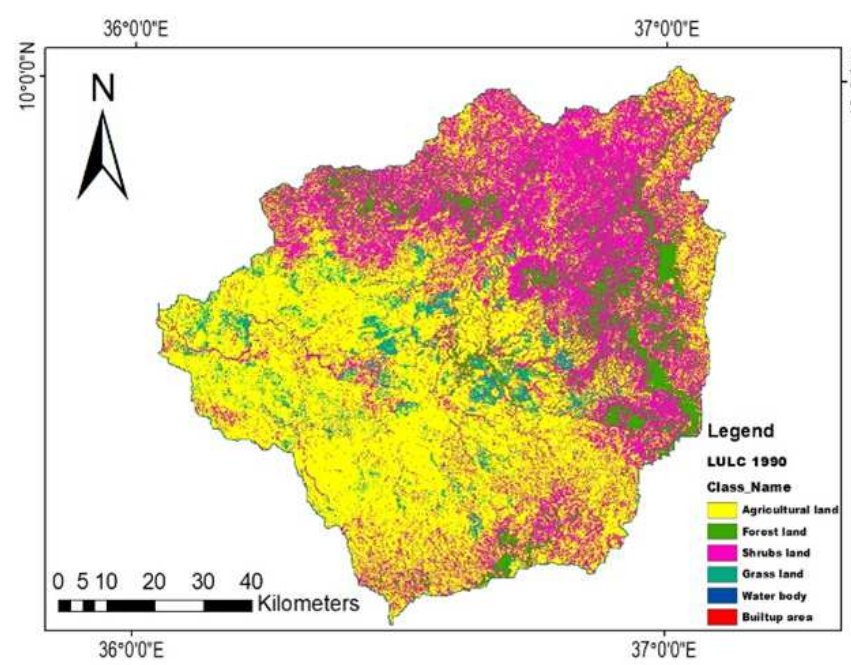

a) 1990

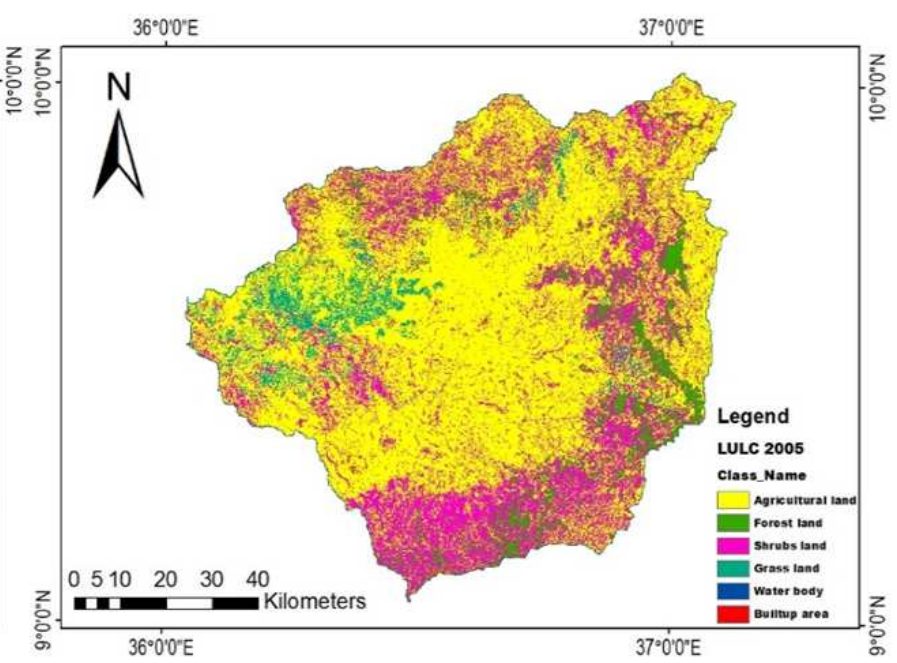

b) 2005

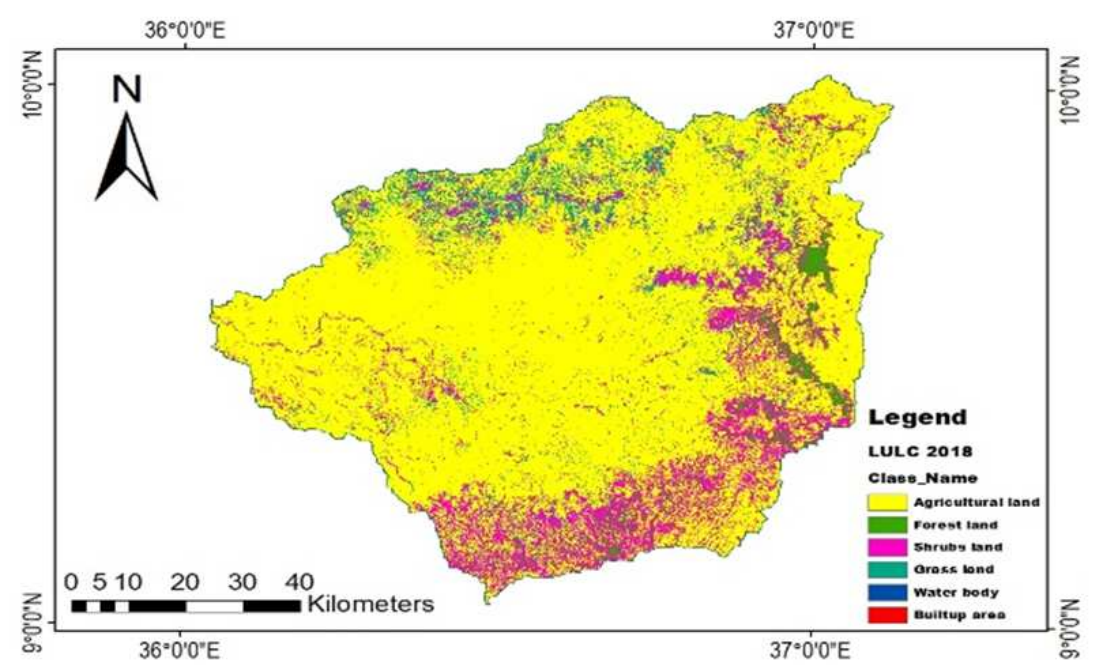

c) 2018

Figure 4. Land use land cover map of the year.

\begin{tabular}{|c|c|c|c|c|c|}
\hline 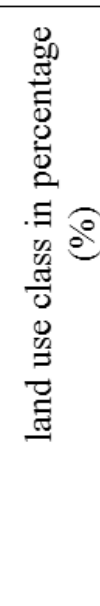 & 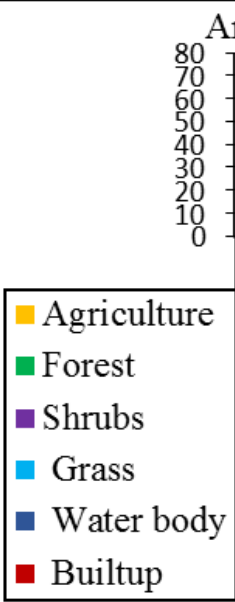 & $\begin{array}{c}1990 \mathrm{LU} \\
52.25 \\
10.13 \\
32.58 \\
4.92 \\
0.06 \\
0.06\end{array}$ & $\begin{array}{c}2005 \mathrm{LU} \\
61.84 \\
7.86 \\
24.94 \\
4.47 \\
0.05 \\
0.84\end{array}$ & $\begin{array}{c}2018 \mathrm{LU} \\
78.03 \\
2.45 \\
13.46 \\
4.07 \\
0.04 \\
1.95\end{array}$ & Year \\
\hline
\end{tabular}

Figure 5. Area coverage of land use/cover classes in percentage for 1990, 2005 \& 2018 map.

The agricultural land and built-up area increased during the first period (1990 to 2005), with $+9.60 \%$ and $+0.78 \%$ respectively.
On other hand, forest land, shrubs land, grassland, and water bodies have shown a significant decrease in the first period. Again, agricultural land and built-up area 
increased during the second period (2005 to 2018), and for the overall study period (1990 to 2018), the agricultural land coverage increased by $+25.79 \%$, and built-up area increased by $+1.89 \%$ mainly because of the population growth that caused the increase in demand for new cultivation land and settlement expansion and infrastructures. But, forest land, shrubs land, grassland, and water bodies showed decreased. This reveals that the changes in one land use cover resulted in a change in the other land cover types.

Table 2. Land use land cover classes detection of Angar sub-basin.

\begin{tabular}{|c|c|c|c|c|c|c|c|}
\hline Land use & change & 2005- 1990 & & 2018-2005 & & 2018-1990 & \\
\hline Class Name & SWAT Code & Area (ha) & $(\%)$ & Area (ha) & $(\%)$ & Area (ha) & $(\%)$ \\
\hline Agriculture & AGRC & 75742.5 & 9.6 & 127715 & 16.19 & 203457 & 25.79 \\
\hline Forest & FRSE & -17912 & -2.27 & -42640 & -5.41 & -60552 & -7.68 \\
\hline Shrubs & FRST & -60233 & -7.64 & -90552 & -11.48 & -150785 & -19.12 \\
\hline Grass & PAST & -3548.4 & -0.45 & -3193.5 & -0.4 & -6742 & -0.86 \\
\hline Water body & WATR & -72.7 & -0.01 & -78.93 & -0.01 & -151.65 & -0.02 \\
\hline Built-up & URLD & 6121.9 & 0.78 & 8749.14 & 1.11 & 14871 & 1.89 \\
\hline
\end{tabular}

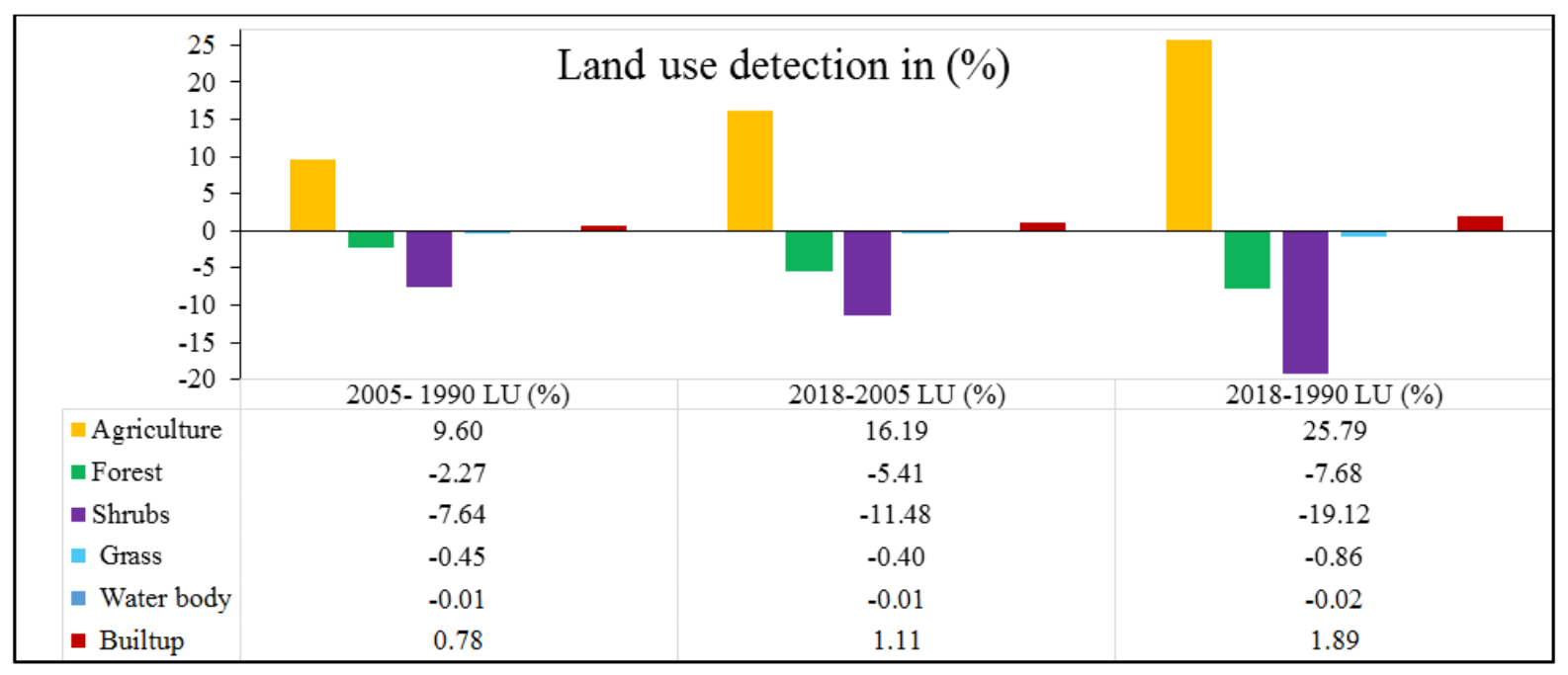

Figure 6. Land use/cover classes detection in percentage (1990-2018).

\subsection{Stream Flow Modeling}

Sensitivity analysis of simulated stream flow for the watershed was performed using the daily observed flow for identifying the most sensitive parameter. After parameters were checked for sensitivity and eight sensitive parameters were identified. Calibration was done for sensitive flow parameters of SWAT with observed average monthly stream flow data. The modeling of stream flow was calibrated and validated with a time series dataset from 1990 to 2005 . The first two years of the modeling period were used for model warm-up. Data for the period 1992 to 1999 were used for calibration and 2000-2005 for validation.

Table 3. Parameters highly sensitive to stream flow.

\begin{tabular}{|c|c|c|c|c|c|c|c|}
\hline Rank & Parameter Name & Description of parameters & t- Stat & P-Value & Min. value & Max. Value & Fitted Value \\
\hline 1 & $\mathrm{~V}-\mathrm{CN} 2 . \mathrm{mgt}$ & SCS runoff curve number & -14.5 & $1.00 \mathrm{E}-24$ & 35 & 90 & 66.50 \\
\hline 2 & V-ALPHA_BF & Base flow alpha factor & 8.18 & $4.00 \mathrm{E}-12$ & 0 & 1 & 0.25 \\
\hline 3 & V-ESCO_hru & Soil evaporation compensation factor & 2.43 & 0.017 & 0 & 1 & 0.65 \\
\hline 4 & V-GW_DELAY & Groundwater delay & -6.08 & $2.00 \mathrm{E}-09$ & 0 & 500 & 250 \\
\hline 5 & V-CH_N2 & Manning's n value for main channel & 0.78 & 4.40E-01 & -0.01 & 0.3 & 0.16 \\
\hline 6 & V-CH_K2 & Channel effective hydraulic conductivity & 0.67 & 5.07E-01 & 0 & 10 & 4.5 \\
\hline 7 & V-GWQMN & Threshold depth of water in the shallow aquifer for return & 5.94 & 7.00E-08 & -650 & 0 & -500 \\
\hline 8 & V-Gw_Revap & Ground water revap coefficient & -4.26 & $6.00 \mathrm{E}-05$ & -1.0 & 0 & -0.5 \\
\hline 9 & V-RCHRG.DP.gw & Deep aquifer percolation & 0.502 & $6.20 \mathrm{E}-01$ & 0 & 5 & 1.05 \\
\hline 10 & R-SOL_AWC & Available water content of soil & 0.56 & 5.81E-01 & 0 & 1 & 0.270 \\
\hline 11 & V-HRU-SLP.hru & Average slope steepness & 0.51 & $6.20 \mathrm{E}-01$ & 0 & 1 & 0.706 \\
\hline
\end{tabular}

\subsubsection{Stream Flow Calibration}

The performance for stream calibration, using land-use of 2005 , the coefficient of determination $\mathrm{R}^{2}$, and Nash-Sutcliffe Equation (NSE) were 0.93 and 0.92 respectively, and also for land use of 1990 and 2018 performance values were presented in (Table 4). 


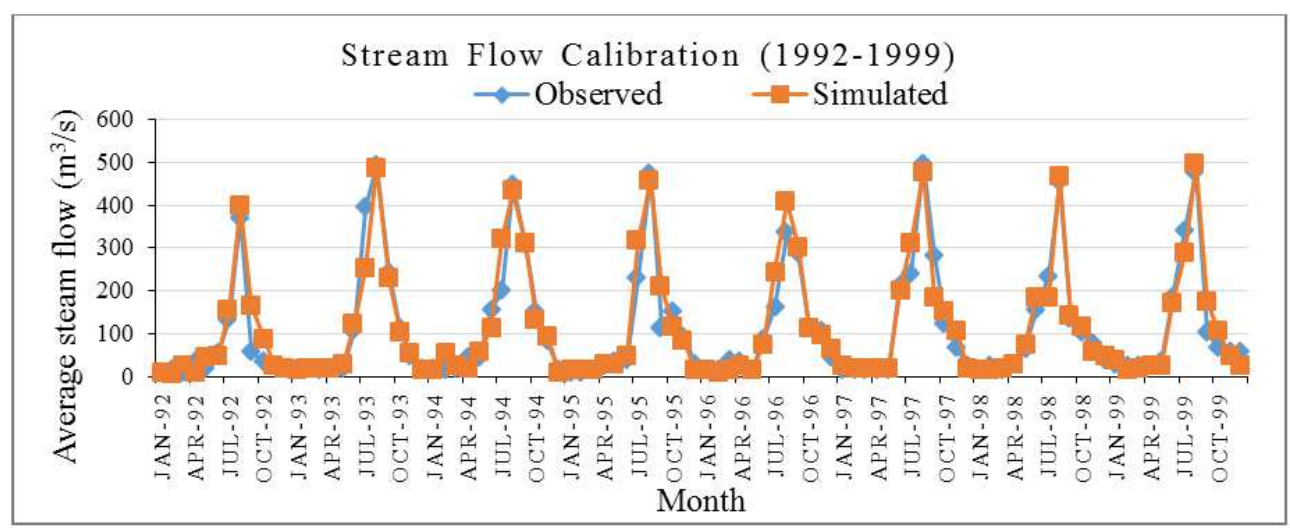

Figure 7. Average monthly observed and simulated flow Calibration (1992-1999) using land use 2005.

The result indicates the performance of the model in prediction was shown a good agreement between the observed and simulated flow and the scatter plot showing the observed and simulated values for calibration was shown in (Figure 8).

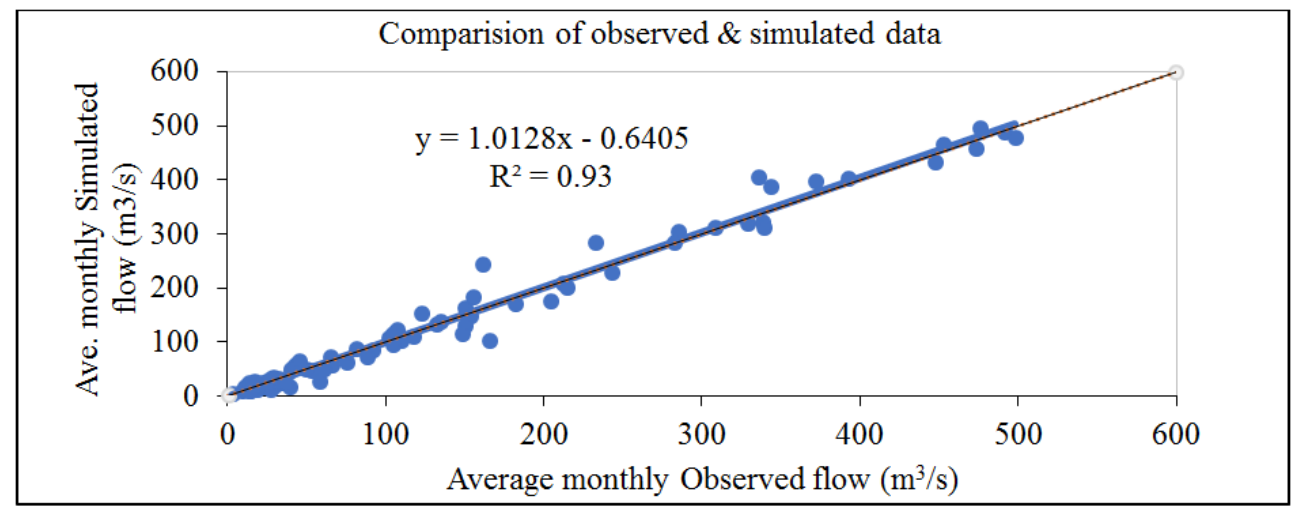

Figure 8. Scatter Plot of observed versus simulated flow during calibration period (1992-1999) using land use 2005.

\subsubsection{Stream Flow Validation}

After calibration, the stream flow was validated from January 1, 2000, to December 31, 2005, for 6 years. The validation performance, using land-use of 2005, the coefficient of determination $\mathrm{R}^{2}$ was 0.92 , and Nash-Sutcliffe Equation (NSE) was 0.91 and also for land use of 1990 and 2018 performance values were presented in (Table 4).

Table 4. Summary of Steam flow calibrated and validated performance evaluations.

\begin{tabular}{lllllll}
\hline \multirow{2}{*}{ Performance } & Calibration & & \multicolumn{3}{c}{ Validation } \\
\cline { 2 - 6 } & $\mathbf{1 9 9 0}$ & $\mathbf{2 0 0 5}$ & $\mathbf{2 0 1 8}$ & $\mathbf{1 9 9 0}$ & $\mathbf{2 0 0 5}$ \\
\hline $\mathrm{R}^{2}$ & 0.86 & 0.93 & 0.87 & 0.83 & 0.92 & 0.84 \\
$\mathrm{NSE}$ & 0.74 & 0.92 & 0.82 & 0.64 & 0.91 & 0.76 \\
\hline
\end{tabular}

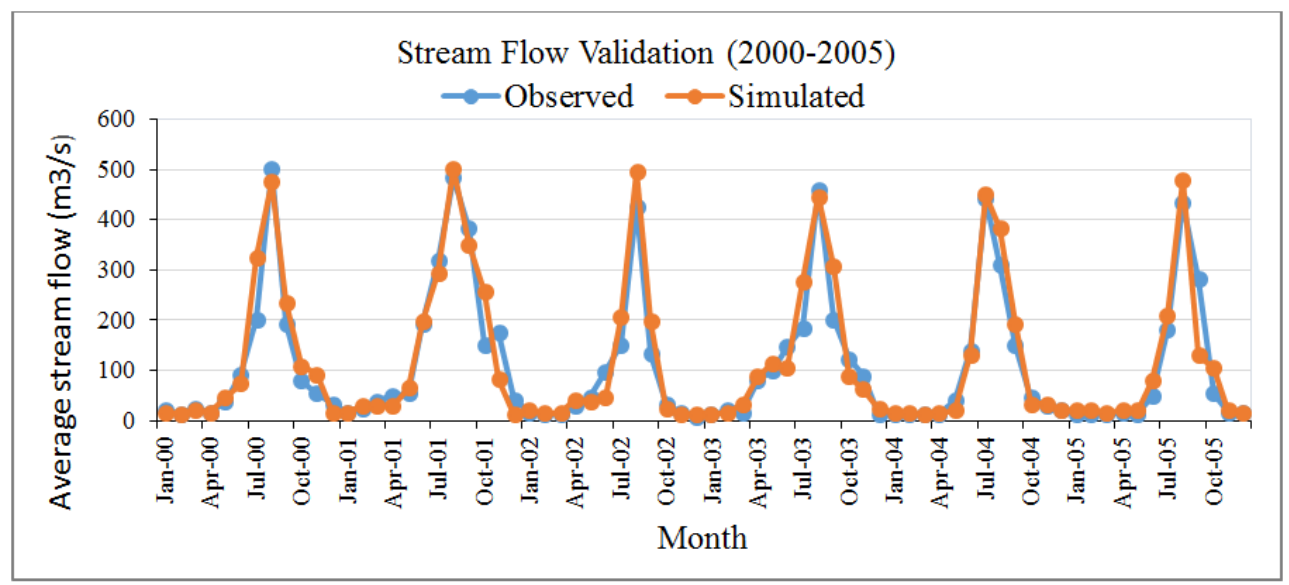

Figure 9. Average monthly observed and simulated flow Validation (2000 - 2005) using land use 2005. 
The result indicates the performance of the model in prediction was shown a good agreement between the observed and simulated flow and the scatter plot showing the observed and simulated values for validation was shown in (Figure 10).

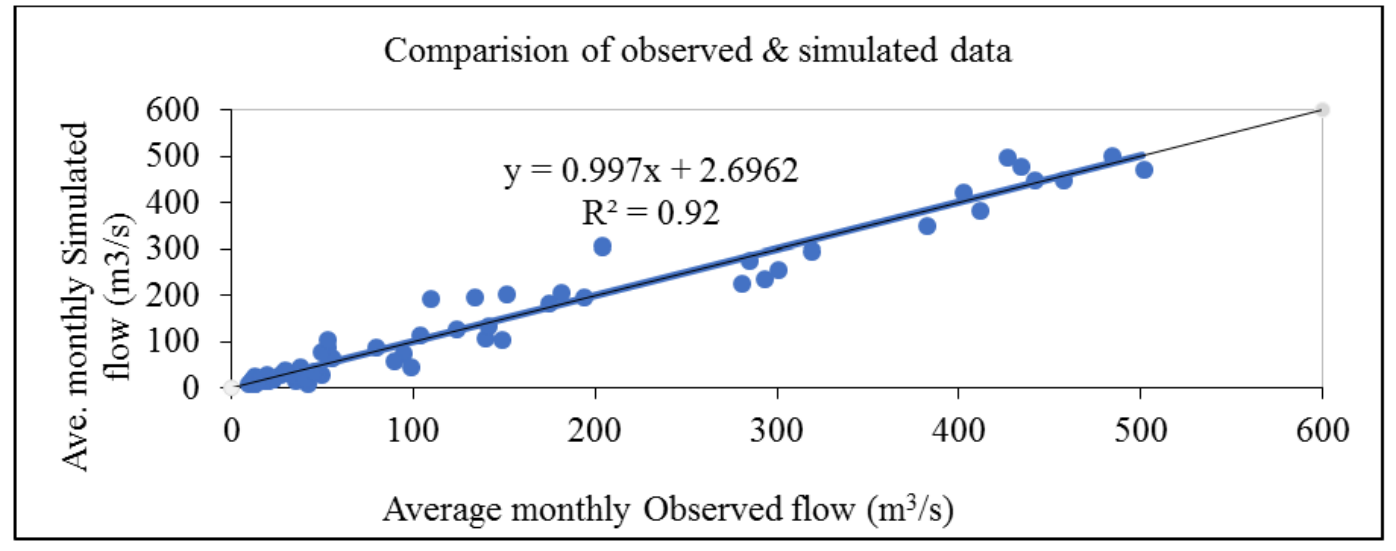

Figure 10. Scatter Plot of observed versus simulated flow during validation period (2000-2005) using land use 2005.

\subsection{Sediment Yield Modeling}

The amount of sediment yield from the Angar Sub-basin was simulated by considering the land use/cover change from 1990 to 2018 . The Sensitivity analysis of simulated sediment yield for the sub-basin was performed using the monthly observed sediment yield for identifying the most sensitive parameter and for further calibration of the simulation of sediment yield. The most sensitive sediment parameters [USLE Soil erodibility factor (USLE_K), USLE support practice factor (USLE_P), Channel reentrainment exponent parameter (SPEXP), channel cover factor (CH_COV2), and Channel erodibility factor (CH_COV1)] were checked for sensitivity and sensitive parameters were identified.

\subsubsection{Sediment Yield Calibration and Validation}

Sediment simulated was also used for further calibration and validation in comparison with the observed sediment flow at the Great Angar gauging station, which was estimated by using the sediment yield versus discharge rating curve developed.

Hence, after automatically calibrating and also identifying the sensitive and significant parameters manual calibration was also performed. This was done by simulating the sediment for the period of January 1, 1992, to December 31, 1999, and two-year warm-up period, and for validation from January 1, 2000, to December 31, 2005, for each land use/cover of 1990, 2005 and 2018. The model calibrated and validated performance using $\mathrm{R}^{2}$, and NSE values presented in (Table 5). The co-relationship between monthly predicted and observed sediment yield shown a good agreement.

Table 5. Performance evaluation of calibrated and validated sediment yield.

\begin{tabular}{lllllll}
\hline \multirow{2}{*}{ Performance } & Calibration & & \multicolumn{3}{c}{ Validation } \\
\cline { 2 - 6 } & $\mathbf{1 9 9 0}$ & $\mathbf{2 0 0 5}$ & $\mathbf{2 0 1 8}$ & $\mathbf{1 9 9 0}$ & $\mathbf{2 0 0 5}$ \\
\hline $\mathrm{R}^{2}$ & 0.87 & 0.79 & 0.81 & 0.83 & 0.87 & 0.78 \\
NSE & 0.65 & 0.73 & 0.72 & 0.68 & 0.85 & 0.74 \\
\hline
\end{tabular}

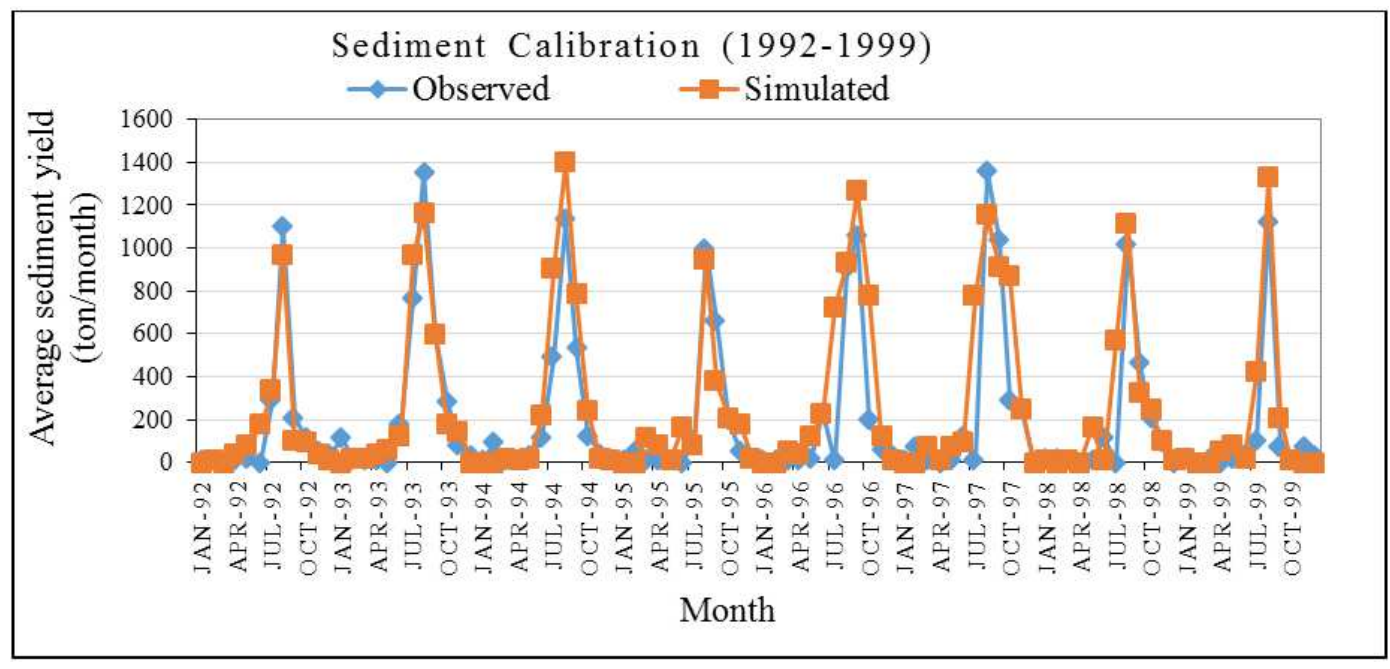

Figure 11. Average monthly observed and simulated sediment yield calibration for 2005 land use. 


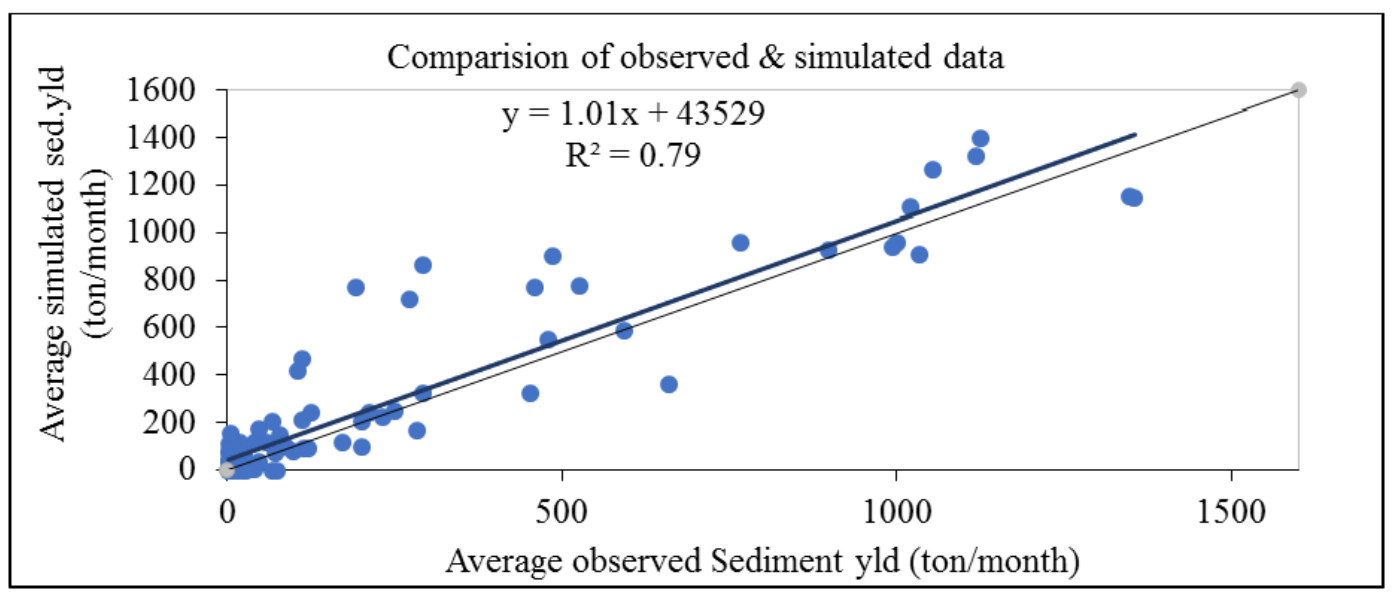

Figure 12. Scatter Plot of average observed versus simulated Sediment yield during calibration period for 2005 land-use.

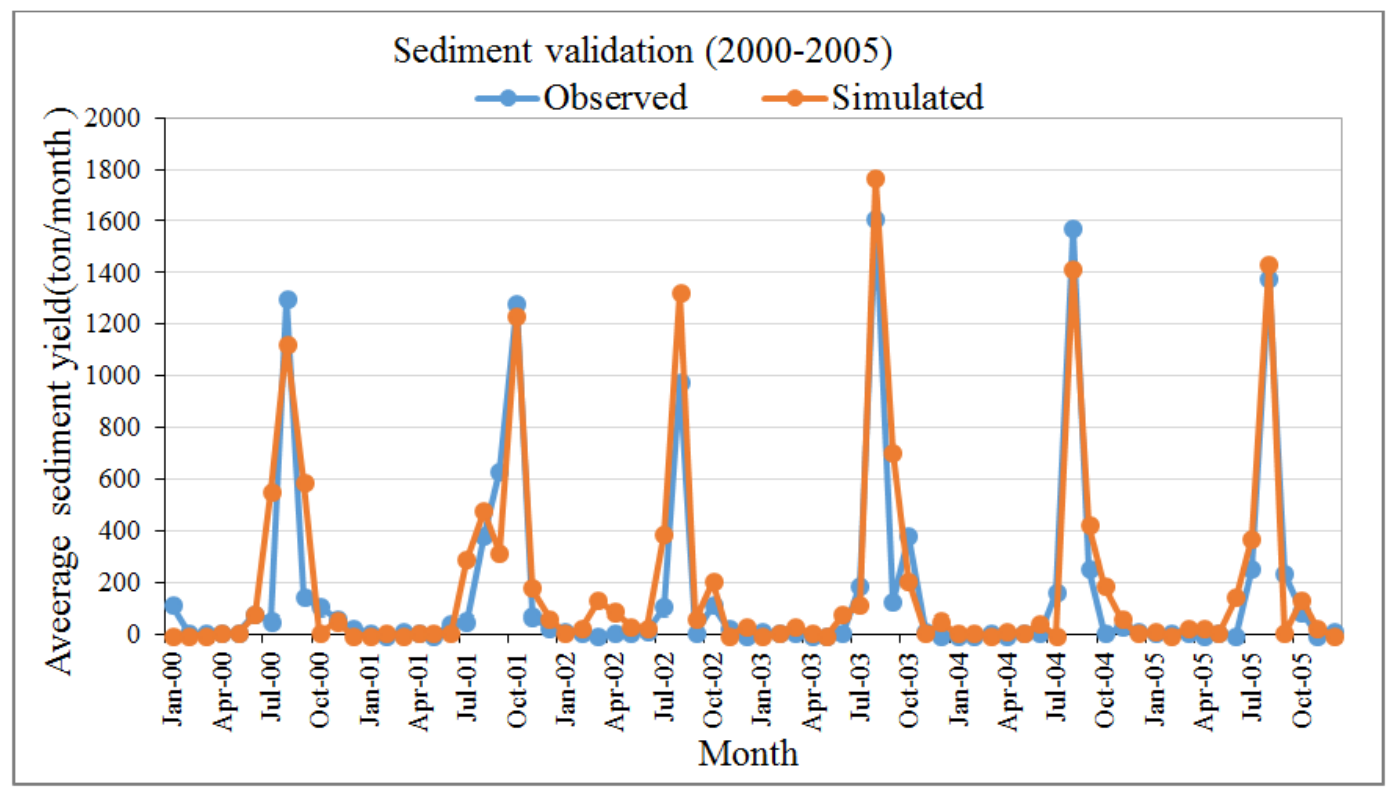

Figure 13. Average monthly observed and simulated sediment yield Validation for 2005 land use.

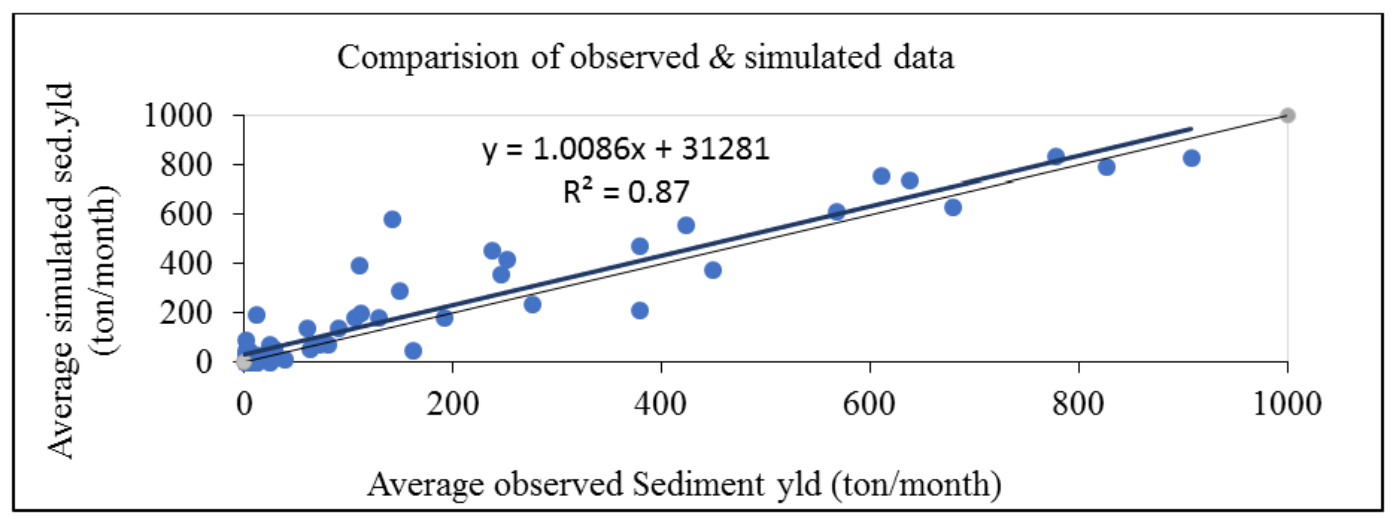

Figure 14. Scatter Plot of average observed versus simulated Sediment yield during Validation period for 2005 land-use.

\subsubsection{Evaluation of Sediment Yield Due to Land Use/Cover Change}

The land use land cover dynamics were assessed after three independent simulations for three land uses of 1990, 2005, and 2018 by SWAT model carried out with keeping other input parameters the same and the model result was calibrated and validated for sediment yield generation from the area. The result of the simulation showed that the annual average simulated sediment yields $18 \mathrm{t} / \mathrm{ha} / \mathrm{yr}, 19 \mathrm{t} / \mathrm{ha} / \mathrm{yr}$. and $22 \mathrm{t} / \mathrm{ha} / \mathrm{yr}$. using land-use of 1990, 2005, and 2018 respectively, and the annual average measured suspended sediment generated from the sediment rating curve was 17.64 
t/ha/yr. which is more closed to simulated sediment yield values.

Generally, the simulated sediment yield increased by 4 t/ha/yr. from land-use of 1990 to 2018. It increased from year to year due to land use/cover changes, the agriculture land increased and other land-use types reduced resulting in high soil erosion from the watershed. Agriculture land increased by $9.6 \%, 16.19 \%$, and $25.79 \%$ during using land-use of (1990-2005), (2005-2018) and (1990 - 2018) and also the sediment yield increased by $1.0 \mathrm{t} / \mathrm{ha} / \mathrm{yr}$., $2.0 \mathrm{t} / \mathrm{ha} / \mathrm{yr}$. and 4 t/ha/yr. respectively.

The temporal variability of sediment in the area results in the higher amount of sediment that occurred during June, July, August, and September due to high peak runoff consequently results in a high rate of soil erosion and sediment load from the area. On the other hand, a very low rate of soil erosion or sediment load generation was during dry seasons which had a very small amount of runoff flow.

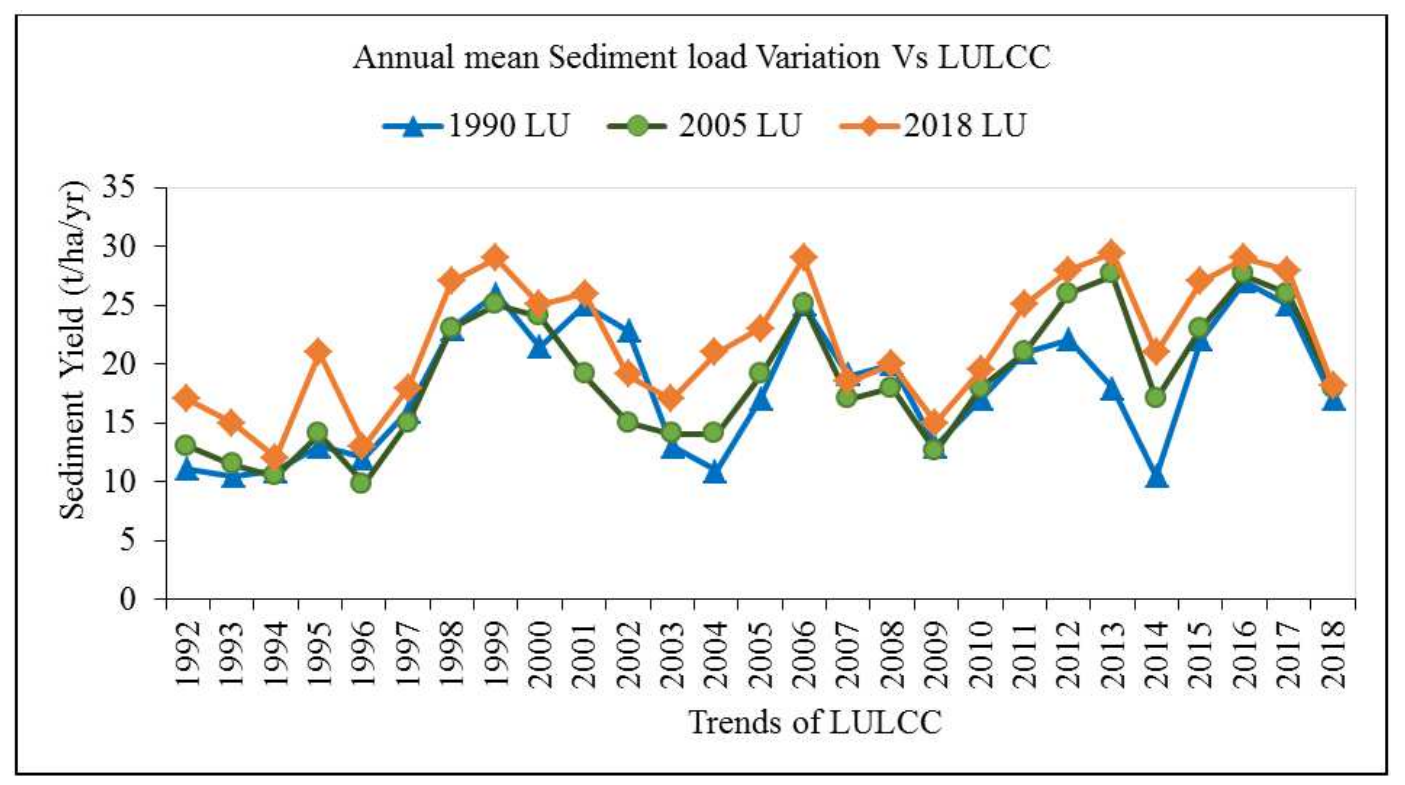

Figure 15. Annual mean sediment yield for the trends of LULCC in Angar sub-basin.

Spatial variability of sediment yield from the Angar sub-basin was identified from the validated sediment output for each sub-basin. The assessment of the spatial variability sediment yield is useful for watershed management planning and identifying the most erodible catchment. Identification and ranking of critical erosionprone areas is an important consideration for policymakers to implement best management strategies that are more sustainable in the future for the long-term use of these natural resources [7]. The sediment yield was a direct relationship with the land use/cover, soil, and slope of a watershed, and also different amounts of sediment load were generated from each sub-watershed area. From the first simulation using land-use of 1990, the sediment load distribution throughout the area ranges from 0.21 ton/ha/year to 36.34 ton/ha/year, while the second and third simulation using land-use of 2005 and 2018, the sediment load ranges from 0.28 ton/ha/year to 40.86 ton/ha/year and 0.30 ton/ha/year to 56.01 ton/ha/year respectively. This indicates the sediment yield increased due to the direct and indirect consequences of land use/cover dynamics.

Table 6. Spatial Variation of annual average Sediment yield (t/ha/yr.) using 1990, 2005 \& 2018 land use for sub-watersheds of Angar sub-basin.

\begin{tabular}{|c|c|c|c|c|c|c|c|}
\hline Sub-w/shed & $1990 \mathrm{LU}(\mathrm{t} / \mathrm{h} / \mathrm{yr})$. & $2005 \mathrm{LU}$ (t/h/yr.) & 2018 LU (t/h/yr.) & Sub-w/shed & 1990 LU (t/h/yr.) & 2005 LU (t/h/yr.) & 2018 LU (t/h/yr.) \\
\hline $\mathrm{N}-1$ & 17.8 & 21.82 & 23.69 & $\mathrm{~N}-15$ & 0.21 & 0.28 & 16.55 \\
\hline $\mathrm{N}-2$ & 7.15 & 12 & 21.88 & $\mathrm{~N}-16$ & 10.36 & 24.72 & 16.26 \\
\hline $\mathrm{N}-3$ & 5.11 & 6.8 & 16.32 & $\mathrm{~N}-17$ & 19.24 & 20.87 & 14.84 \\
\hline $\mathrm{N}-4$ & 6.39 & 15.47 & 26.56 & $\mathrm{~N}-18$ & 6.6 & 7.62 & 10.89 \\
\hline N-5 & 3.17 & 13.39 & 19.5 & N-19 & 5.8 & 8.1 & 2.93 \\
\hline N-6 & 12.38 & 13.6 & 18.4 & $\mathrm{~N}-20$ & 25.96 & 13.29 & 18.72 \\
\hline $\mathrm{N}-7$ & 13.7 & 14.18 & 19.1 & $\mathrm{~N}-21$ & 36.34 & 40.86 & 56.01 \\
\hline $\mathrm{N}-9$ & 16.47 & 21.42 & 16.86 & $\mathrm{~N}-23$ & 10.63 & 15.06 & 38.85 \\
\hline $\mathrm{N}-10$ & 8.31 & 11.3 & 15.87 & $\mathrm{~N}-24$ & 12.38 & 15.04 & 21.33 \\
\hline $\mathrm{N}-11$ & 2.58 & 11.26 & 11.8 & $\mathrm{~N}-25$ & 11.06 & 14.99 & 16.07 \\
\hline $\mathrm{N}-12$ & 0.9 & 7.33 & 6.96 & Total & 277.25 & 350.92 & 453.37 \\
\hline $\mathrm{N}-13$ & 0.95 & 1.01 & 0.3 & Average & 11.09 & 14.04 & 18.13 \\
\hline $\mathrm{N}-14$ & 1.53 & 3.81 & 3.41 & & & & \\
\hline
\end{tabular}




\subsubsection{Ranking and Mapping the Sediment Yield Potential Source Area}

The sub-watershed is covered with cultivated land or agricultural land susceptible to erosion and results in the highest sediment yield. The spatial distribution of sediment yields out of 25 sub-watersheds, the 20 sub-watersheds produce average annual sediment yields above 12 ton/ha/yr. and the highest sediment loading was 56.01 ton/ha/year from sub-watershed number 21 in the 2018 year. This implies that the higher sediment yield was due to the land use/cover change, especially, the expansion of agriculture activities and settlement areas can cause high sediment load from the watershed.
The estimated sediment yield rate from sub-watershed ranges from 0.21 to $36.34 \mathrm{t} / \mathrm{ha} /$ year in the 1992 year, 0.28 to $40.86 \mathrm{t} / \mathrm{ha} /$ year, and 0.30 to $56.01 \mathrm{t} /$ ha respectively whereas the annual weighted average soil loss rate from the watershed was estimated $11.09 \mathrm{t} / \mathrm{ha} /$ year in $1992,14.04 \mathrm{t} / \mathrm{ha} /$ year in 2005 and $18.13 \mathrm{t} / \mathrm{ha} /$ year in 2018 . According to FAO degree of erosion classification, the soil erosion level in the watershed categorized as none to slight $(0-11 \mathrm{t} / \mathrm{ha} / \mathrm{year})$, slight (11-20 t/ha/year), moderate (20-50 t/ha/year), high/severe (50-106 t/ha/year), and very severe (>106 $\mathrm{t} /$ ha/year). The spatial distribution map in Figure 16 below, indicates the potential source of sediment loading of the study area.

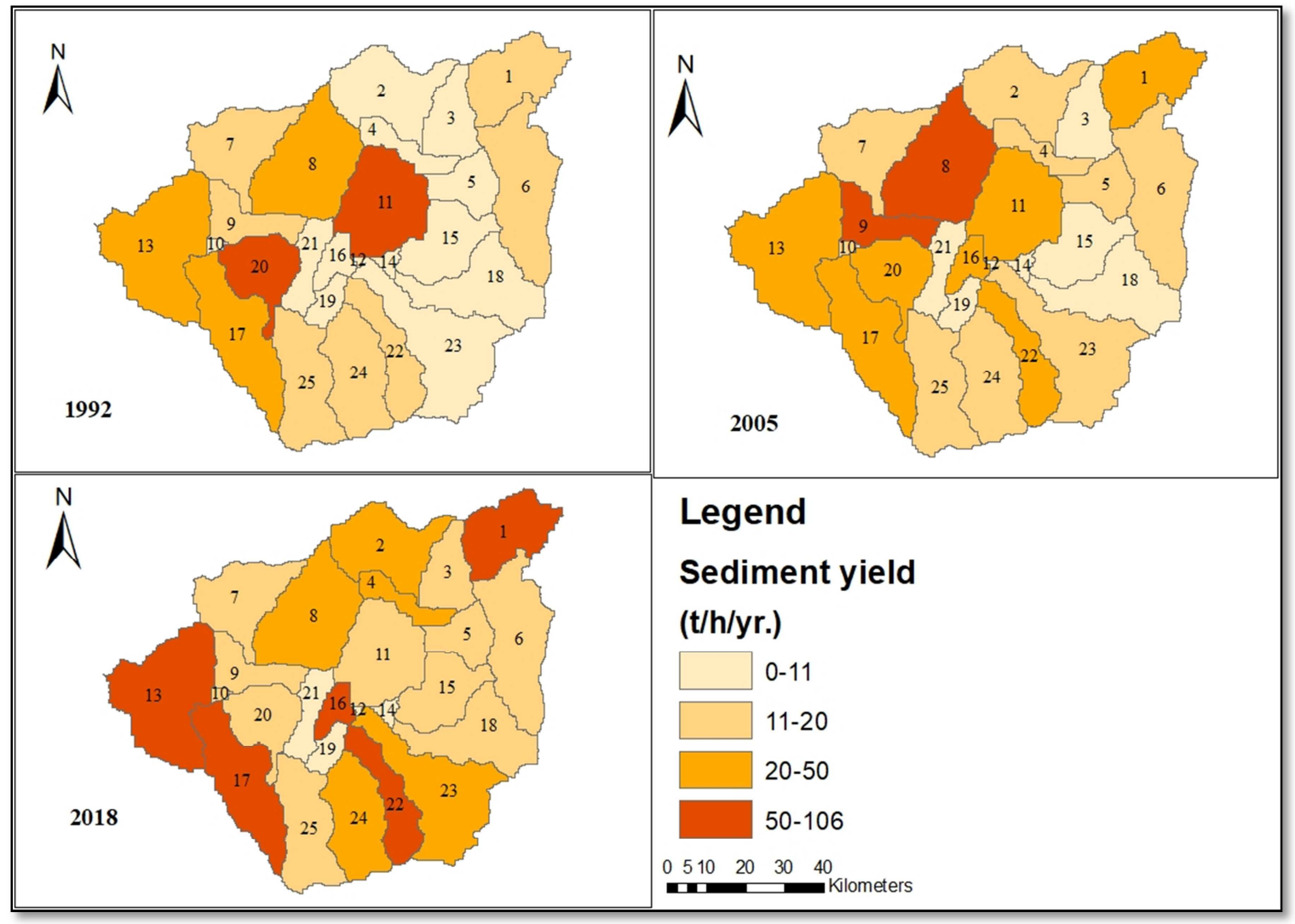

Figure 16. Spatial distribution of the annual mean simulated sediment yield map of 1992, 2005 \& 2018 year.

The sub-watersheds, which produced more than $11 \mathrm{t} /$ ha/year are identified as erosion critical areas [6]. From the result, the severity erosion potential of Angar sub-basin was $34.69 \%$ under slight, $9.67 \%$ under high/severe using land-use of 1990 , and also about $33.99 \%$ under moderate and $9.95 \%$ under a severe degree of erosion using land-use of 2005. On other hand using land-use of 2018 , about $24.32 \%$ under high/severe degree of erosion problem within the Angar sub-basin.

\section{Conclusions}

The land use/cover dynamics effects on sediment yield of the watershed were assessed and analyzed statistically using hydrological model SWAT 2012 with integrated ArcGIS. The land use/cover changes in the Angar sub-basin were identified from TM, ETM+, and OLI_TIRS satellite images, and land use/cover maps of the years 1990, 2005, and 2018 were prepared and the accuracy assessments of the three maps were checked using the error matrix and Kappa statistic. The simulation was carried out three times by physical-based model SWAT using three independent land use of 1990, 2005, and 2018. The result revealed that land use significantly changed from the 1990 to 2018 period. The agricultural land coverage increased by $52.25 \%, 61.84 \%$, and $78.03 \%$ using land use of 1990, 2005, and 2018 respectively. On other hand, forests, shrubs, grassland, and water bodies decreased. This indicated the cultivation activity and settlement area increased. 
The stream flow and sediment were calibrated and validated for the performance of the model. Using coefficient of determination $\left(\mathrm{R}^{2}\right)$ and Nash-Sutcliffe efficiency (NSE), the performance has shown that, a good match between the measured and simulated sediment load. The annual average measured suspended sediment generated from the sediment rating curve was $17.64 \mathrm{t} / \mathrm{ha} / \mathrm{yr}$. and the simulated annual average sediment yield was $18 \mathrm{t} / \mathrm{ha} / \mathrm{yr}, 19 \mathrm{t} / \mathrm{ha} / \mathrm{yr}$, and 22 t/ha/yr using land-use of 1990, 2005, and 2018 respectively. The sediment yield increased by $4 \mathrm{t} / \mathrm{ha} / \mathrm{yr}$. from land-use of 1990 to 2018 , as result of agriculture increased by $25.79 \%$, from land-use of 1990 to 2018 and built-up area by $1.89 \%$. The severity erosion potential area contributing of subwatersheds of Angar sub-basin was about $34.69 \%$ of the watershed area was under slight, 9.67\% under high/severe of erosion using land-use of 1990 and also about $33.99 \%$ under moderate and $9.95 \%$ under a severe degree of erosion using land-use of 2005. On other hand using land-use of 2018, about $24.32 \%$ under high/severe degree of erosion problem within the Angar sub-basin. Generally, the SWAT model carried out well in predicting the sediment yield under land use/cover dynamics from the Angar sub-basin and the study result were acceptable and this study was required for better watershed management purposes.

\section{References}

[1] Arnold, J. G. (1998). Large Area Hydrological Modeling and Assessment. Part I. Model Development J. America Water Resource ASSOC, 34: 73-89.

[2] Asselman, N. (2000). Fitting and Interpretation of Sediment Curves. Journal of Hydrology, 243: 228-248.

[3] Aster D. Y. and Seleshi B. A. (2009). Characterization and Atlas of the Blue Nile Basin and Its sub-basin. International Water Management Institute.

[4] Bosch, J. J. (1982). Areview of Catchment Experiments to Determine the Effect of Vegetation Changes on Water Yield and Evaporation.
[5] Easton Z. M., F. D. (2010). A multi-basin SWAT Analysis of Runoff and Sedimentation in Blue Nile, Ethiopia. Department of Biological and Environmental Engineering, Cornell University, Ithaca, NY 14853, USA.

[6] FAO. (1998). The Soil and Terrain Database for Northeastern Africa.

[7] Haptamu I. G. (2010). Watershed Sediment Yield Modeling for each Scarcer Area.

[8] Hurni H. (1988). Degradation and Conservation of the Soil Resource in the Ethiopia Highlands.

[9] Leopold, L. B. (1992). Fluvial processes in geomorphology. San Fransisco: W. H. Freeman and Company.

[10] Neitsch, S. A. (2005). Soil and Water Assessment Tool, Theoretical Documentation: Version Temple, TX.. USDA Agricultural Research Service and Texas A \& M Blackland Research Center.

[11] Rawat, J. S. (2005). Monitoring Land use/cover Change Using Remote Sensing and GIS Techniques. A case of study of Hawalbagh block, Disrict Almora, Uttarakhand, India, National Authority for Remote Sensing and Space Sciences. The Egyptian Journal of Remote and space sciences, 18, 77-84.

[12] USDA-SCS. (1972). National Engineering Handbook, Section 4. Washington, DC.: Hydrology. U.S. Government Priting Office.

[13] Van Rompaey, A. O. (2001). Modeling Mean Annual Sediment Yield Using A Distributed Approach. Earth Surf. Proc. Landf., 26: 1221-1236.

[14] Walling D. E. (1994). Measuring Sediment Yield from River Basins in Lal, Red., soil Erosion Research Methods. Soil and Water Cnservation Society, Ankeny, IA.

[15] Wermer C. et al. (1986). Soil Conservation Experiments in Anjeni, Gojam Research Unit, Ethiopia.

[16] Williams, J. R. (1975). Sediment yield prediction with Universal Equation using Runoff Energy factor. In present and prespective technology for predicting sediment yield and sources: Preceeding of the sediment yield workshop, USDASedimentation Lab. Oxford, MS, November 28-30. 